Up to half of the children in our study had $\mathrm{Cl}$ difficile isolated from the stool with no associated faecal toxin; this has been noted before. The absence of any clinical differences between those who do and those who do not have the organism (and whether toxigenic or non-toxigenic in vitro) and a similar incidence of isolation of the organism among controls support the notion that the presence of $\mathrm{Cl}$ difficile alone and without demonstrable faecal toxin is not primarily pathogenic.

The lesser incidence of the organism in our control group despite a threefold increase in antibiotic usage is of interest and confirms the findings of the Swedish group who found that $\mathrm{Cl}$ difficile occurred numerically more often in children who had not been treated by antibiotics than in those who had been given such drugs. ${ }^{8}$ This may be related to the more frequent use of the antianaerobic antibiotic erythromycin in the controls. Alternatively children who have gastroenteritis may be more prone to $\mathrm{Cl}$ difficile associated diarrhoea and colitis. Thus other microorganisms are found in three quarters of patients (Ellis et al, to be published); the incidence of toxin in our gastroenteritis group was twice that of the controls; and parallel experience from adult cases suggests that disturbance in bowel function due to causes other than antibiotics may also predispose to $\mathrm{Cl}$ difficile diarrhoea. ${ }^{2}$

The role of $\mathrm{Cl}$ difficile cytotoxin in children with gastroenteritis is not totally clear; many recover spontaneously, whereas the clinical condition of others demands treatment, to which they apparently respond. For children who are not that ill guidelines for treatment are lacking. Sigmoidoscopic and histological appearances of the rectal mucosa may be normal (especially if the disease is proximal) or non-specific; and toxin titres often bear little relation to severity of the disease. In view of the disastrous consequences of failure to treat some cases ${ }^{4}$ it seems prudent to treat all children who have symptoms and toxin in the stool with at least five days of oral vancomycin.

We are most grateful to D M Jones, director of the Public Health Laboratory, Withington, for his generous contribution of the use of the laboratory facilities in this study. We also thank Sisters M Coyle, $\mathrm{N}$ Fosbrook, and $\mathrm{S}$ Thompson and the nursing staff of the paediatric wards at Monsall Hospital for their efficient and untiring contribution in making the study run smoothly. Mr Andrzej Makowski, of the department of statistics, North West Regional Health Authority, gave expert help with the statistical data.

\section{References}

${ }^{1}$ Brettle RP, Poxton IR, McMurdoch J, et al. Clostridium difficile in association with sporadic diarrhoea. Br Med f 1982;284:230-3.

${ }^{2}$ Ellis ME, Watson B, Milewski PJ, Jones G. Clostridium difficile colitis unassociated with antibiotic therapy. Br f Surg 1983;70:242-3.

${ }^{3}$ Rietra PJGM, Slaterus KW, Meuwissen SGM, Zanen HC. Clostridial toxin in faeces of healthy infants. Lancet 1978;ii:319.

4 Richardson SA, Brookfield DSK, French TA, Gray J. Pseudomembranous colitis in a 5-week-old infant. Br Med $\mathcal{F} 1981 ; 283: 1510$.

5 Ellis ME, Watson B, Mandal BK, et al. Contemporary gastroenteritis of infancy: clinical features and prehospital management. Br Med f 1984; 288:521-3.

- Mandal BK, Watson B, Ellis ME. Pseudomembranous colitis in a 5-weekold infant. Br Med F 1982;284:345-6.

7 Greenfield C, Aguilar-Ramirez JR, Pounder RE, et al. Clostridium difficile and inflammatory bowel disease. Gut 1983;24:713-7.

${ }^{*}$ Holst E, Helin I, Per-Anders M. Recovery of Clostridium difficile from children. Scand $\mathcal{F}$ Infect Dis $1981 ; 13: 41-5$.

(Accepted 25 November 1983)

\title{
Analysis of T cell subsets in Graves' disease: alterations associated with carbimazole
}

\author{
MARIAN E LUDGATE, ALAN M MCGREGOR, ANTHONY P WEETMAN, \\ SUVINA RATANACHAIYAVONG, JOHN H LAZARUS, REGINALD HALL, \\ GORDON W MIDDLETON
}

\begin{abstract}
Conflicting data on subpopulations of peripheral blood lymphocytes in patients with autoimmune disease largely reflect variations in methods of study. An investigation was therefore conducted aimed at avoiding this difficulty.

Serial samples of peripheral blood mononuclear cells from 42 patients with hyperthyroid Graves' disease were collected at monthly intervals before, during, and for 12
\end{abstract}

\footnotetext{
Departments of Medicine and Medical Physics, Welsh National School of Medicine, Cardiff

MARIAN E LUDGATE, PHD, research associate

ALAN M MCGREGOR, MD, MRCP, Wellcome senior fellow and honorary consultant physician

ANTHONY P WEETMAN, MD, MRCP, lecturer in medicine

SUVINA RATANACHAIYAVONG, MD, research associate

JOHN H LAZARUS, MD, FRCP, senior lecturer and honorary consultant physician

REGINALD HALI, MD, FRCP, professor of medicine

GORDON W MIDDLETON, MSC, senior physicist
}

Correspondence to: Dr Alan M McGregor, Department of Medicine, Welsh National School of Medicine, Heath Park, Cardiff CF4 4XN. months after a six month course of carbimazole. Samples were stored in liquid nitrogen until completion of the study, when they were thawed and all samples from each patient analysed within the same assay using mouse monoclonal antibodies to human cell subsets and a fluorescence activated cell sorter. Proportions of cytotoxic/suppressor (OKT8) positive cells before treatment (mean 17.4 (SEM 0.8)\%) were significantly lower $(p<0.001)$ than those in normal controls $(29.8(1.9) \% ; n-10)$ and returned to normal by the end of treatment. In contrast, the proportions of activated $T$ cells (OKIa-OKM1) were significantly raised before treatment as compared with normal (14.4 (0.6)\% versus $4.6(0.8) \%$; $<<0.001)$ and fell to normal by the end of treatment. Proportions of OKT3 and OKT4 positive $T$ cells remained unchanged throughout treatment and in the succeeding 12 months. In patients who relapsed after treatment there was a rise in the proportion of activated $T$ cells and a fall in OKT8 positive $T$ cells, which returned towards normal with retreatment.

The explanation for the alterations in numbers of circulating $T$ cells remains to be determined but they may provide a means for predicting more accurately the outcome of Graves' disease after treatment with carbimazole. 


\section{Introduction}

Hyperthyroid Graves' disease, an organ specific autoimmune disease, is probably due to autoantibodies which, by binding in the region of the thyroid follicular cell thyrotrophin receptor, stimulate thyroid function.' Although this pathogenetic process is now relatively well characterised, the aetiological events precipitating autoantibody production remain poorly understood. Much interest has focused on the concept that organ specific autoimmune disease arises because of defective suppressor $\mathrm{T}$ lymphocyte function, ${ }^{2}$ and Volpé and his colleagues, in studies on autoimmune thyroid disease, have provided evidence for impaired responsiveness of suppressor $\mathrm{T}$ cells in these patients. ${ }^{3}$

In parallel with these functional studies of $T$ cells several groups have sought to quantify the numbers of $T$ cell subsets in autoimmune thyroid disease, but with conflicting results. ${ }^{4} 9$ Various criticisms, often pertaining to methods used, may be levelled at those studies and may help to explain the discrepant results. In trying to resolve the problem we have investigated the patterns of $T$ cell subsets in patients with well characterised Graves' disease before, during, and for 12 months after a course of antithyroid drugs. Before doing so we investigated the possibility of cryopreserving peripheral blood mononuclear cells in liquid nitrogen and thence using the lymphocytes, obtained on thawing the mononuclear cells, for enumeration of T lymphocyte subsets. Using cells from normal subjects, we first established that no differences in numbers of $T$ cells were detectable in cryopreserved cells as compared with fresh (non-frozen) cells ${ }^{10}$; we then stored monthly samples of peripheral blood mononuclear cells from patients with Graves' disease, so that at the end of the study we could assay all the samples from each patient within the same assay. This paper reports the results.

\section{Subjects and methods}

Peripheral blood mononuclear cells isolated by Ficoll-Hypaque density centrifugation from $10-20 \mathrm{ml}$ heparinised blood were obtained at the same time of day at monthly intervals from 42 patients ( 7 men, 35 women) with hyperthyroid Graves' disease (diagnosed clinically, biochemically, and by radioisotope scan). Ceils were obtained before, during a six month course of carbimazole ( $40 \mathrm{mg}$ daily, supplemented after four to six weeks with $80 \mu \mathrm{g}$ triiodothyronine daily), and for the succeeding 12 months after completion of treatment. In addition peripheral blood mononuclear cells from 10 normal control subjects were collected on a single occasion and thereafter treated in the same way as the cells from the patients. Data are presented for the 29 patients in whom all samples collected before and during treatment were available and for the 25 patients who had been followed up for at least six months after their course of treatment. The cells were washed three times in Roswell Park Memorial Institute (RPMI) 1640 culture medium, and after counting and determining viability with acridine orange and ethidium bromide ${ }^{11}$ they were resuspended at $10 \times 10^{9}$ viable cells $/ 1$. The cells obtained were then frozen in liquid nitrogen to await simultaneous analysis with the peripheral blood mononuclear cells obtained subsequently.

The method for preparing the cells is described elsewhere. ${ }^{10}$ In brief, freezing of cells was performed by adding $250 \mu \mathrm{l}$ neat fetal calf serum to a cell pellet containing $10-20 \times 10^{6}$ peripheral blood mononuclear cells at $4 \mathrm{C}$. Thereafter a $250 \mu \mathrm{l}$ aliquot of four parts fetal calf serum to one part dimethylsulphoxide was added dropwise to the mononuclear cells in fetal calf serum.

The resuspended peripheral blood mononuclear cells (kept on ice in freezing phials) were transferred rapidly to a well insulated polystyrene container and maintained at $-70 \mathrm{C}$ overnight before transfer to a liquid nitrogen storage tank.

Before use all the phials of frozen cells from the same patient were thawed rapidly in a prewarmed water bath $\left(37^{\circ} \mathrm{C}\right)$ and, once the last crystal of ice had melted, transferred to RPMI 1640 at $20^{\circ} \mathrm{C}$, in which they were left for 20 minutes. The thawed cells were washed twice in RPMI 1640 and separated into sheep red blood cell $(E)$ rosette enriched $\left(E^{+}\right)$and rosette depleted $(E)$ populations. ${ }^{12}$ In brief, this was performed by mixing $2 \mathrm{ml}$ fetal calf serum, $5 \mathrm{ml}$ sheep red blood cells $\left(100 \times 10^{9} / 1\right)$, and $4 \mathrm{ml}$ peripheral blood mononuclear cells
(3-5 $\left.\times 10^{9} / 1\right)$ in RPMI medium; the mixture was centrifuged at $300 \mathrm{~g}$ for five minutes and incubated on ice for one hour.

After gentle resuspension the mixture was resuspended with FicollHypaque, and by density centrifugation ( $400 \mathrm{~g}$ for 35 minutes) separation of an $E^{+}$rosette preparation (pellet) from an $E^{-}$population (gradient interface) was achieved. After hypotonic lysis to remove the sheep red cells from the $\mathrm{E}^{+}$population the cells were filtered through a 320 stainless steel mesh to remove cell debris and resuspended in phosphate buffered saline supplemented with albumin $(0.2 \% \mathrm{wt} / \mathrm{vol})$ and sodium azide $(0.2 \% \mathrm{wt} / \mathrm{vol})$ at $20 \times 10^{9} \mathrm{E}^{+}$cells/ 1 and maintained at room temperature. The $\mathrm{E}^{+}$populations were used for $\mathrm{T}$ cell subset analysis using a fluorescence activated cell sorter (FACS III, BectonDickenson) to distinguish and enumerate the cell populations recognised by the commercially available mouse monoclonal antibodies OKT3 (total T cells), OKT4 (helper T cells), OKT8 (suppressor cytotoxic $T$ cells), and OKM1 (monocytes) OKIa (HLA-DR framework) (Ortho-Diagnostics). ${ }^{13} 14$ Briefly, $50 \mu \mathrm{l}$ aliquots of peripheral blood monocytes were treated with $50 \mu \mathrm{l}$ of one in 10 dilution (in phosphate buffered saline and albumin-sodium azide; PBS-AA) of each of the $\mathrm{OK}$ monoclonals and incubated for five minutes at 20 C. Cells were then washed twice in PBS-AA treated with an in house fluorescein labelled sheep antimouse immunoglobulin $(50 \mu \mathrm{l}$ of a one in 10 dilution in PBS-AA) for five minutes at $20^{\circ} \mathrm{C}$, washed as before, resuspended in $1 \mathrm{ml}$ PBS-AA, and kept on ice until counting. Cells counted by flow cytometry were expressed as the percentage of the total cells counted which fluoresced with the particular OK monoclonal. A minimum of 5000 fluorescing cells were counted.

Before, at six weekly intervals throughout the course of treatment and for the first three months after completing treatment, and thereafter at three monthly intervals for the next nine months we assessed the thyroidal 20 minute uptake of iodine-123 ( $\left.{ }^{123} \mathrm{I}\right)$ after triiodothyronine $(80 \mu \mathrm{g}$ daily for a week before estimation of uptake, unless the patient was already taking the drug as part of the blocking and replacement regimen). The uptake measured 20 minutes after an intravenous dose of $1 \mathrm{MBq}(27 \mu \mathrm{Ci})^{123}$ I was corrected for background radioactivity in the neck by measuring a similar area over the thigh. Each patient served as his own control and it was therefore not considered necessary or ethical to establish a range of normal values for ${ }^{123}$ I uptake. A patient's thyroid activity was considered suppressed if the uptake fell below $50 \%$ of the pretreatment value. Analysis of circulating thyroxine concentrations by radioimmunoassay in patients whose thyroidal ${ }^{123} I$ uptake did not fall below $50^{\circ}$; of the pretreatment value after completion of the course of treatment provided evidence of biochemical thyroidal state.

The data were analysed by the unpaired Student's $t$ test.

\section{Results}

Before treatment in patients with hyperthyroid Graves' disease ( $\mathrm{n}-29)$ numbers of circulating OKT3 and OKT4 $\mathrm{T}$ cells were no different from those in the 10 normal controls (see table). In contrast, however, numbers of circulating $\mathrm{OKT}^{+}$cells were lower and numbers of activated $\mathrm{T}$ cells $\left(\mathrm{OKIa}-\mathrm{OKM} 1^{+}\right)$higher in the pretreatment samples from the patients than in the controls (table). These differences were highly significant $(p<0.001)$.

After instituting carbimazole treatment in the patients with Graves' disease there were significant changes in both the activated and $\mathrm{OKT} 8^{+} \mathrm{T}$ cell populations (fig 1 ). Numbers of activated $\mathrm{T}$ cells fell over the six months from a mean pretreatment value of 14.4 (SEM 0.6$)^{\circ}$, to a mean of $4.5(0.4)^{\circ}$, whereas the percentage of OKT 8 cells rose from $17 \cdot 4(0 \cdot 8)$ to $26 \cdot 2(0 \cdot 8)$. These values of activated and $\mathrm{OKT} 8^{+}$cells in the patients with Graves' disease at six months were not significantly different from those obtained in the 10 normal controls (table).

Comparison of $T$ cell subset numbers within $E$ rosette enriched peripheral blood mononuclear cells of patients with Graves' disease and normal control subjects. Values expressed as mean percentage of positive cells (SEM in parentheses)

\begin{tabular}{lcc}
\hline T cell subset & $\begin{array}{c}\text { Control subjects } \\
(\mathrm{n}=10)\end{array}$ & $\begin{array}{c}\text { Patients with } \\
\text { Graves' disease } \\
(\mathrm{n}=29)\end{array}$ \\
\hline OKT3 positive cells & $83 \cdot 2(3 \cdot 0)$ & $78 \cdot 5(1 \cdot 4)$ \\
OKT4 positive cells & $52 \cdot 1(2 \cdot 3)$ & $50 \cdot 6(1 \cdot 4)$ \\
OKT8 positive cells & $29 \cdot 8(1 \cdot 9)$ & $17 \cdot 4(0 \cdot 8)$ \\
Activated T cells (OKIa-OKM1) & $4 \cdot 6(0 \cdot 8)$ & $14 \cdot 4(0 \cdot 6)$ \\
\hline
\end{tabular}


Before treatment the mean thyroidal uptake of ${ }^{123} I$ for the group as a whole $(\mathrm{n}=42)$ was 22.7 (SD 10.9) \% , and on completion of the six month course this had fallen to $10 \cdot 6(5 \cdot 2) \%$.

After completion of a six month course of carbimazole 25 of the patients were followed up whenever possible monthly for the next 12 months. At the time of assay it was possible to subdivide them into two groups-those remaining in remission and those in whom hyperthyroidism had never been controlled (on the basis of their persistently raised thyroidal ${ }^{123}$ I uptake values) or in whom the return of hyperthyroidism (true relapse) had been shown biochemically after clinical suspicion and subsequent return to non-suppressible levels of thyroidal ${ }^{123}$ I uptake.

Thyroidal ${ }^{123} \mathrm{I}$ uptake before beginning treatment (mean 22.5 $(\mathrm{SD} 10 \cdot 4) \% ; n=14)$ and after completion of treatment $(9 \cdot 9(5.4) \%)$ in patients in the remission group was no different from the values in the patients in the relapse group (true relapse plus those whose disease was never controlled by treatment; mean uptake $23.0(\text { SD } 11.5)^{\circ}(n=11)$ before treatment, and $11.2(11.4) \%$ after the six month course of carbimazole). Whereas only seven of the 14 patients in remission and five of the 11 patients in the relapse group showed a fall in thyroidal ${ }^{123}$ I uptake at the end of treatment, all of the patients in remission showed a gradual fall towards normal over the succeeding months of follow up. In contrast, in the relapse group persistently raised uptake values with evidence of biochemical hyperthyroidism were seen in three patients and suggested failure to control the disease. In the remaining eight patients in the relapse group a fall in thyroidal ${ }^{123} I$ uptake over the period after completing treatment was followed by a rise to greater than $50 \%$ of their pretreatment values within three months of stopping treatment in three patients, within six months of stopping treatment in a further three, and within 12 months in the remaining two.

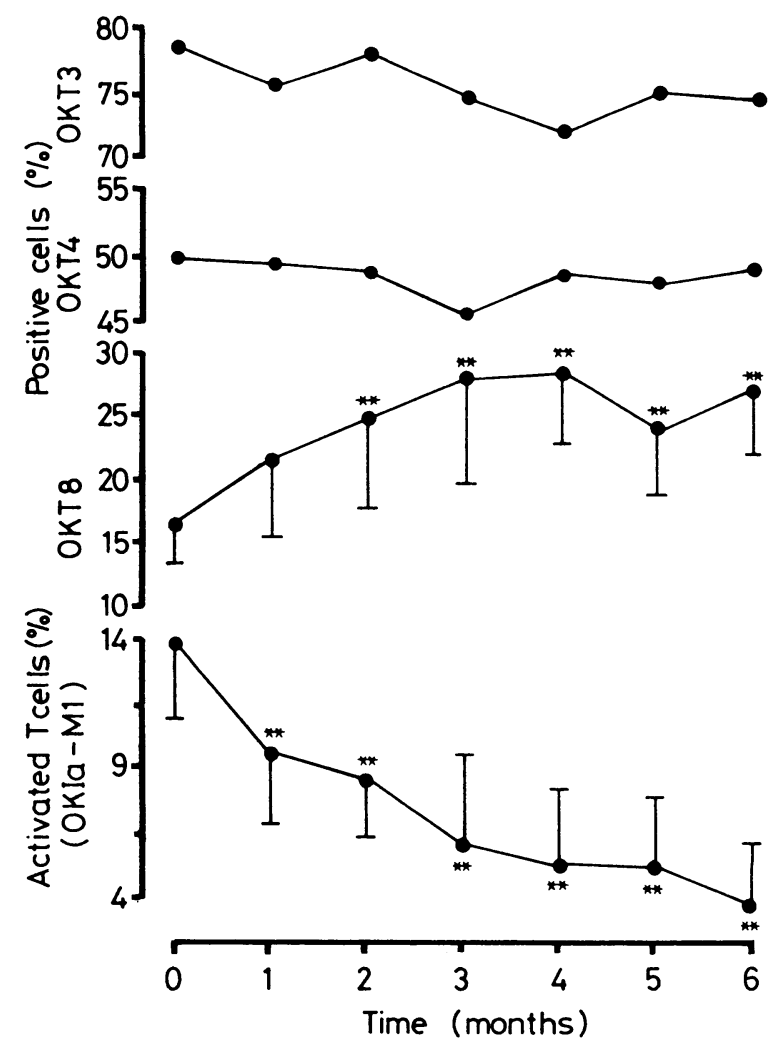

FIG 1-Influence of six month course of carbimazole on peripheral blood T cell subsets of 29 patients with hyperthyroid Graves' disease. Points are means. Bars are SD.

Compared with value at zero time: ${ }^{* *} \mathrm{p}<0.001$.

On the basis of this distinction between patients in the relapse and remission groups, analysis of the patterns of $T$ cell subsets while continuing to show no alteration in numbers of OKT3 and $\mathrm{OKT}^{+}$ $\mathrm{T}$ cells (data not shown) allowed some discrimination of the two groups of patients on the basis of their numbers of OKT8 and activated T cells (fig 2). Whereas in the 14 patients remaining in remission there was no significant alteration in their proportions of OKT8 and

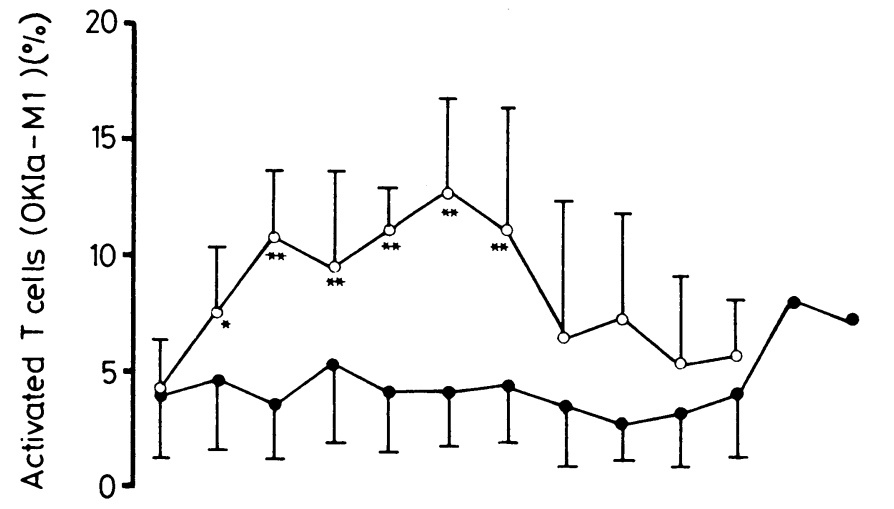

activated T cells over the 12 months this was not the case in the 11 patients in whom relapse was documented. In this latter group proportions of $\mathrm{OKT} 8^{+}$cells were lower and proportions of activated $T$ cells higher than at the same stage in the patients in remission, and these differences were significant (fig 2).

Within individual patients in the relapse group alterations in activated $T$ cells preceded or were present at the time that relapse was confirmed. This was also the case for two of the three patients within the relapse group at the time of stopping treatment, whose disease was never controlled. Numbers of $\mathrm{OKT} 8^{+}$cells, though tending to fall in those who relapsed, were less likely to change before other evidence of relapse. Interestingly, numbers of $T$ cells began to rise after 16 months in the group in remission, although the values did not achieve statistical significance (fig 2). This may have reflected early and further relapses within this group of patients, but it was too early to be certain owing to the small numbers of patients.

\section{Discussion}

By studying individual patients with Graves' disease during the course of their disease and analysing all the samples from each patient within the same assay several features emerged regarding the proportions of circulating $T$ cells. While no changes were observed in total $\mathrm{T}$ cells $\left(\mathrm{OKT}^{+}\right)$or in the number of helper $\mathrm{T}$ cells $\left(\mathrm{OKT}^{+}\right)$in our patients during the study or as compared with values in normal control subjects, this was not the case in respect of cytotoxic/suppressor cells $\left(\mathrm{OKT}^{+}\right)$or activated $\mathrm{T}$ cells. Before treatment, when the patients were hyperthyroid, numbers of OKT8 cells were low and numbers of activated $\mathrm{T}$ cells high. With control of the disease numbers of $\mathrm{OKT} 8^{+}$cells increased and numbers of activated $\mathrm{T}$ cells fell, so that by the end of the six month course of carbimazole values were no different from normal. After the end of treatment two distinct patterns of response emerged. Patients who remained in remission showed little change in their proportions of OKT ${ }^{+}$ and activated $T$ cells. In contrast, patients who relapsed showed 
a return towards the values observed before treatment, with a fall in OKT8 cells and a rise in activated $T$ cells. These changes were often detectable before clinically and biochemically evident disease was recognised (data not shown).

In contrast with other series, we studied single subjects serially and analysed $\mathrm{T}$ cells from each subject in the same assay. In a previous study we established the validity of using cryopreserved peripheral blood mononuclear cells as a source of cells for analysis of $\mathrm{T}$ cell subsets. ${ }^{10}$ In addition, by enriching the cell population by the use of the $E$ rosette technique ${ }^{12}$ for $T$ cells and gating out all cells outside the lymphocyte peak using the FACS we detected negligible B cell contamination $(1 \%)$ of the $T$ cell enriched population. Furthermore, gating out most of the monocytes on the FACS meant that by counting monocytes $\left(\mathrm{OKM} 1^{+}\right)$contaminating the lymphocyte peak and subtracting them from the total number of OKIa ${ }^{+}$cells (B cells, monocytes, and activated $T$ cells) we could arrive at an accurate estimation of activated $T$ cells. ${ }^{1516}$ In this study we therefore excluded contaminating monocytes and $\mathrm{B}$ cells from our $\mathrm{T}$ cell populations and believe that the changes reported reflect alterations in $T$ cells alone. Hence unlike Wall and his colleagues, ${ }^{6}$ we think that the increased proportion of $\mathrm{OKIa}^{+}$cells reflects an increase in activated $T$ cells in untreated hyperthyroid patients rather than an increase in monocytes, and this view is supported by the observations of Canonica et al, who used different markers of $\mathrm{T}$ cells. ${ }^{9}$

In comparing the proportions of suppressor cells $\left(\mathrm{OKT} 8^{+}\right)$ observed in our patients with those reported by others it is apparent that while a number of groups have documented low values in single samples from patients with untreated hyperthyroid Graves' disease, ${ }^{4}{ }^{58}{ }^{9}$ this is by no means a consistent finding. ${ }^{6} 7$ The explanation for the discrepancy remains uncertain. Clearly not all hyperthyroidism is due to Graves' disease and not all patients with Graves' disease are necessarily hyperthyroid, so that careful documentation of thyroidal state and disease aetiology is crucial. By examining serial samples during the disease within an individual we have tried to obviate this criticism. With the increasing variety of monoclonal antibodies available for examining $T$ cells it is clear that differences in numbers of $T$ cells might reflect differences in the cell populations recognised by these antibodies. Furthermore, in some of the studies reported the technique of counting fluorescent cell numbers by eye is open to observer variation, which we avoided by using a cell sorter. With the finding that $T$ cells have a circadian rhythm ${ }^{17} 18$ it becomes important to ensure that samples are taken at the same time if comparison between them is to be valid, and in our study patients were seen and bled at a regular clinic between 1030 am and noon. Clearly, therefore, in reporting and assessing data on alterations in $T$ cell subsets with time or between subjects it becomes critical to recognise the variables potentially inherent in such a study, since they may otherwise themselves be associated with alteration in the cell numbers which are mistakenly taken to reflect changes due to the disease.

Having tried to recognise and avoid the potential problems inherent in such a study, we have detected consistent changes in circulating $\mathrm{OKT} 8^{+}$and activated $\mathrm{T}$ cells, which altered with the state of the disease. We cannot explain these changes. It is difficult to see how such "mass effects" on numbers of T cells can have pathogenic implications when we are dealing with an organ specific autoimmune disease in which only a limited number of self antigens are recognised by the immune system and therefore only a fraction of the total $T$ cell numbers can be antigen specific in their recognition of the thyroid autoantigens concerned. Furthermore, it is clear from recent studies that no correlation exists between assessment of $T$ cell function and the numbers of $T$ cells present as assessed by $T$ cell markers. ${ }^{19} 20$

Interestingly, increased numbers of activated $T$ cells are detectable in type I diabetes of recent onset but disappear with progression of the disease at a stage when islet $\beta$ cells have been destroyed. ${ }^{16}$ Hence the presence of increased numbers of activated $T$ cells (possibly in conjunction with decreased numbers of suppressor cells) probably reflects activation of the immune system. In this context our previous data on the immunosuppressive properties of carbimazole ${ }^{21} 22$ may have important implications, since the ability of this drug to influence the immune system may play a central part in controlling the disease.

If these changes in numbers of $T$ cells reflect activation of the immune system the mechanism for their induction remains unknown. Other studies have suggested that raised concentrations of thyroid hormones may be implicated in inducing the alterations in $\mathrm{T}$ cells observed, ${ }^{2}{ }^{6}$ though clearly this does not explain why such $\mathrm{T}$ cell alterations should occur in other organ specific autoimmune diseases in which thyroid hormone values are normal. Furthermore, neither in animals ${ }^{23}$ nor in normal subjects treated with triiodothyronine ${ }^{24}$ have we been able to show any influence of these hormones on immune function; and the findings of Canonica and his colleagues, in showing no $T$ cell changes in patients with hyperthyroidism due to causes other than Graves' disease, strengthen this argument.

In summary, therefore, by using $\mathrm{E}$ rosette enriched $\mathrm{T}$ cell populations obtained from previously frozen peripheral blood mononuclear cells from patients with Graves' disease, we have examined the alterations of $T$ cell subsets in individual patients during the course of the disease within the same assay. The low proportions of suppressor cells and high proportions of activated $T$ cells before treatment with carbimazole returned towards normal with treatment but reverted to pretreatment values in patients who relapsed. Although the explanation for these changes remains unknown, it is clear that while they are unlikely to have any functional significance they may well have an important role in attempts to predict the likely response to treatment in patients with Graves' disease.

This work was supported by funding from the Welsh Office and the Wellcome Trust. We acknowledge the expert technical advice on the FACS from Dr Terry Hoy and the excellent secretarial help of Miss Annette Berry.

\section{References}

1 Adams DD. Thyroid-stimulating autoantibodies. Vitam Horm 1980;38: 120-203.

2 Strakosch CR, Wenzel BE, Row VV, Volpé R. Immunology of autoimmune thyroid disease. N Engl f Med 1982;307:1499-1507.

${ }^{3}$ Okita N, Row VV, Volpé R. Suppressor T-lymphocyte deficiency in Graves' disease and Hashimoto's thyroiditis. $\mathcal{f}$ Clin Endocrinol Metab $1981 ; 52: 528-33$.

4 Thielemans C, Vanhaelst L, Jonckheer M, De Waele M, Van Camp B. Autoimmune thyroiditis: a condition related to a decrease in $\mathrm{T}$ suppressor cells. Clin Endocrinol (Oxon) 1981;15:259-63.

5 Sridama V, Pacini F, De Groot LJ. Decreased suppressor T-lymphocytes in autoimmune thyroid diseases detected by monoclonal antibodies. $\mathcal{f}$ Clin Endocrinol Metab 1982;54:316-9.

6 Wall JR, Baur R, Schleusener H, Bandy-Dafoe P. Peripheral blood and intrathyroidal mononuclear cell populations in patients with autoimmune thyroid disorders enumerated using monoclonal antibodies. $\mathcal{f}$ Clin Endocrinol Metab 1983;56:164-9.

? Iwatani Y, Amino N, Mori H, et al. T lymphocyte subsets in autoimmune thyroid diseases and subacute thyroiditis detected with monoclonal antibodies. $\mathcal{F}$ Clin Endocrinol Metab 1983;56:251-4.

${ }^{8}$ Bonnyns M, Bentin J, Devetter G, Duchateau J. Heterogeneity of immunoregulatory $T$ cells in human thyroid autoimmunity: influence of thyroid status. Clin Exp Immunol 1983;52:629-34.

9 Canonica GW, Bagnasco M, Ferrini S, Biassoni P, Giordano G, Corte G. Circulating $T$-cell subsets in Graves' disease: differences between patients with active disease and in remission after ${ }^{131}$ I therapy. Clin Immunol Immunopathol 1983;28:265-71.

10 Ludgate ME, Dryden PR, Weetman AP, McGregor AM. T cell analysis of cryopreserved peripheral blood mononuclear cells. Immunol Lett 1983; 7:119-22.

11 Parks DR, Bryan VM, Oi VT, Herzenberg LA. Antigen-specific identification and cloning of hybridomas with a fluorescence activated cell sorter. Proc Natl Acad Sci USA 1979;76:1962-6.

12 Dean JH, Silva JS, McCoy JL, Leonard CM, Cannon GB, Herberman RB. Functional activities of rosette separated human peripheral blood leukocytes. F Immunol 1975;115:1449-55.

${ }^{13}$ Kung PC, Goldstein G, Reinherz EL, Schlossman SF. Monoclonal antibodies defining distinctive human $\mathrm{T}$ cell surface antigens. Science 1979 ; 206:347-9. 
14 Hoffman RA, Kung PC, Hansen WP, Goldstein G. Simple and rapid measurement of human $T$ lymphocytes and their subclasses in peripheral blood. Proc Natl Acad Sci USA 1980;77:4914-7.

15 Greaves MF, Verbi W, Festenstein H, Papasteriadis C, Jaraquemada D, Hayward A. "Ia-like" antigens on human T cells. Eur $\mathcal{F}$ Immunol 1979; 9:356-62.

16 Jackson RA, Morris MA, Haynes BF, Eisenbarth GS. Increased circulating Ia-antigen-bearing $\mathrm{T}$ cells in type I diabetes mellitus. $N$ Engl $\mathcal{J}$ Med $1982 ; 306: 785-8$.

17 Bertouch JV, Roberts-Thomson PJ, Bradley J. Diurnal variation of lymphocyte subsets identified by monoclonal antibodies. $\mathrm{Br} \mathrm{Med} \mathcal{f}$ 1983;286:1171-2.

${ }^{18}$ Ritchie AWS, Oswald I, Micklem HS, et al. Circadian variation of lymphocyte subpopulations: a study with monoclonal antibodies. $\mathrm{Br}$ Med F 1983;286:1773-5.

19 Alexander GJM, Nouri-Aria KT, Eddleston ALWF, Williams R Contrasting relations between suppressor-cell function and suppressorcell number in chronic liver disease. Lancet 1983;i:1291-3.
20 Schandené L, Vanden Steen F, Romasco F, Wybran J. Active T rosettes human autologous $\mathrm{T}$ rosettes, OKT8 and OKT4 cells, Con A-induced suppressive activity and autoantibodies: clinical correlations. Clin Immunol Immunopathol 1983;28:147-54.

${ }^{21}$ McGregor AM, Petersen MM, McLachlan SM, Rooke P, Smith BR, Hall R. Carbimazole and the autoimmune response in Graves' disease. N Engl f Med 1980;303:302-7.

22 Weetman AP, McGregor AM, Hall R. Methimazole inhibits thyroid autoantibody production by an action on accessory cells. Clin Immunol Immunopathol 1983;28:39-45.

23 Weetman AP, McGregor AM, Rennie DP, Hall R. Thyroid hormones fail to influence experimental autoimmune thyroiditis. Clin Exp Immunol $1982 ; 50: 51-4$

24 Weetman AP, McGregor AM, Ludgate M, Hall R. The effect of triiodothyronine on normal human lymphocyte function. $\mathcal{f}$ Endocrinol (in press).

(Accepted 1 December 1983)

\section{SHORT REPORTS}

\section{Kaposi's sarcoma in a geriatric patient}

The traditional view of Kaposi's sarcoma has been of a benign disease presenting as dark blue or purple-brown nodules or plaques on the feet occurring more commonly in southern Europeans and Jews and being 14 times more common among men than women. In homosexual men and other immunocompromised patients, however, the disease has recently been reported to behave like an aggressive lymphoma. ${ }^{1-3}$ Such a presentation was previously thought common only in equatorial Africa, where children are affected in a way reminiscent of Burkitt's lymphoma. Immunosuppression by prior infection with cytomegalovirus may be an aetiological factor. ${ }^{4}$ The histological features of affected lymph nodes have been described. ${ }^{5}$ I report a case that emphasises that rapidly fatal Kaposi's sarcoma may occur in groups other than the severely immunocompromised.

\section{Case report}

A 77 year old Russian Jewish woman presented to the geriatric ward via casualty. She gave a two month history of falls, anorexia, and weight loss and also complained of general malaise and night sweats. She had undergone bowel resection for cancer of the colon 12 years previously. On examination she was feverish and had hepatosplenomegaly with widespread lymphadenopathy in the axillas and groins; external iliac nodes were also palpable. No skin lesions were present.

Full blood count showed moderate macrocytic anaemia. Haemoglobin

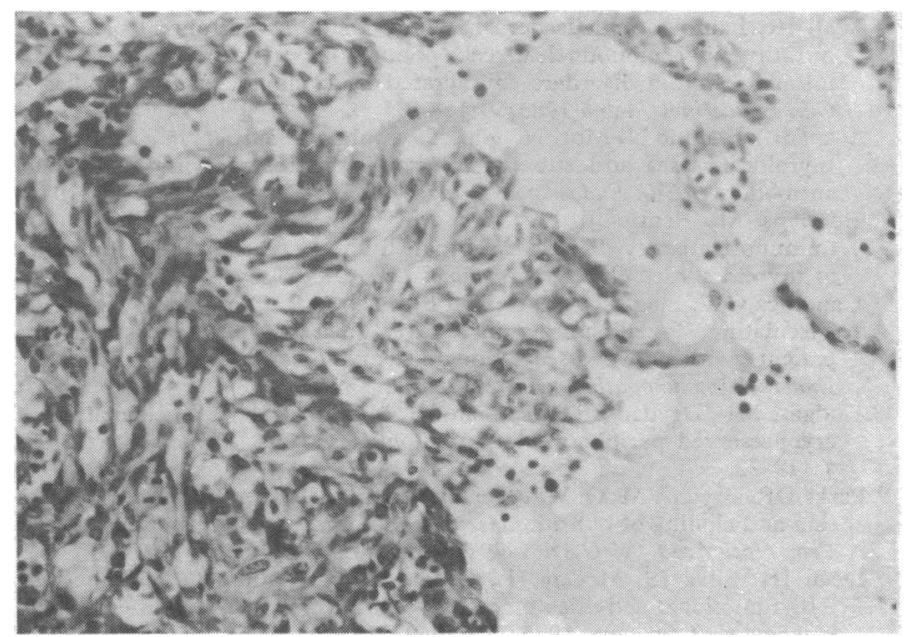

Kaposi's sarcoma of lymph node. Node is partially replaced by proliferation of spindle cells forming mesh. Extravasated red cells are present in tissue spaces. ( $\times 250$ magnification). concentration was $9.8 \mathrm{~g} / \mathrm{dl}$, mean corpuscular volume $104 \mathrm{fl}$, white cell count $4.6 \times 10^{9} / 1$ with a normal differential, and erythrocyte sedimentation rate $127 \mathrm{~mm}$ in the first hour. Chest radiography and routine liver function tests yielded normal results. A random blood glucose concentration was 6.3 $\mathrm{mmol} / 1(114 \mathrm{mg} / 100 \mathrm{ml})$. Serum protein electrophoresis showed an increase in $x_{1}$ and $x_{2}$ globulins and a polyclonal increase in $\gamma$ globulins. Serum concentrations of vitamin $B_{12}$ and folate were within normal ranges. Iliac crest bone marrow aspirate and a trephine biopsy specimen showed mild megaloblastosis with no evidence of malignant infiltration. Antibody tests did not show recent infection with a virus, including cytomegalovirus. Histological examination of a biopsy specimen from an axillary lymph node showed reactive hyperplasia with several peripheral foci of Kaposi's sarcoma (figure). Cultures of the lymph node, blood, and bone marrow yielded no micro-organisms.

She was treated as an outpatient with four courses of bleomycin, cyclophosphamide, vincristine, and prednisolone. She made a good initial response, the liver, spleen, and lymph nodes all decreasing in size, but while receiving prednisolone she developed frank diabetes mellitus that required treatment with diet and chlorpropamide. Six months after presentation lymphadenopathy and hepatosplenomegaly recurred, and she was readmitted to hospital and given a fifth course of chemotherapy. Ten days later she developed the physical signs of consolidation in the right lower lobe, confirmed by chest radiography, from which she subsequently died. No causative organism was found on culture of sputum, and permission for necropsy was refused.

\section{Comment}

This case is interesting not only because the patient was elderly and female but also because of the aggressive nature of the disease and the absence of skin lesions. Nothing in her history suggested that she had immunosuppression before chemotherapy was started, and nothing suggested a recent viral illness that might have altered her immunity. Her death may have been due to an opportunistic infection, but it coincided with a fall in white cell count after chemotherapy and she also had iatrogenic diabetes mellitus. I suggest that this patient developed Kaposi's sarcoma because of her ethnic background rather than because of an acquired immunodeficiency state.

${ }^{1}$ Hymes KB, Greene JB, Marcus A, et al. Kaposi's sarcoma in homosexual men-a report of eight cases. Lancet 1981 ;ii:598-600.

2 Safai B, Good RA. Kaposi's sarcoma. A review of recent developments. CA $1981 ; 31: 2-12$.

${ }^{3}$ Friedman-Kien A, Laubenstein L, Marmor M, et al. Kaposi's sarcoma and pneumocystic pneumonia among homosexual men-New York City and California. MMWR 1981;30:305-8.

4 Giraldo G, Beth E, Huang ES. Kaposi's sarcoma and its relationship to cytomegalovirus (CMNV). III. CMV DNA and CMV early antigens in Kaposi's sarcoma. Int $\mathcal{f}$ Cancer 1980 ;26:23-9.

${ }^{5} \mathrm{O}$ 'Connell KM. Kaposi's sarcoma in lymph nodes: histological study of lesions from 16 cases in Malawi. $\mathcal{F}$ Clin Pathol 1977;30:696-701.

(Accepted 9 November 1983)

Royal Free Hospital, London NW3

N K HARRISON, MA, MRCP, senior house officer

Correspondence to: Dr N K Harrison, Brompton Hospital, Fulham Road, London SW3 6HP. 